\title{
Timeline of Dostoevskii's Life and Works
}

1821 Dostoevskii is born November 11 (October 30, old style) in Moscow.

1825 Serial publication of Pushkin's novel Eugene Onegin begins.

1825 Decembrist uprising in St. Petersburg.

1828 Tolstoi born.

1831 Dostoevskii and his brother attend school in Moscow (until 1836).

1836 Publication of Chaadaev's “First Philosophical Letter”; publication of Dickens's Sketches by Boz.

1837 Pushkin dies in a duel; Dostoevskii's mother dies of tuberculosis and the Dostoevskii brothers are sent to a St. Petersburg boarding school.

1838 Dostoevskii enters military engineering school in St. Petersburg.

1839 Dostoevskii's father is killed (allegedly murdered by his own serfs).

1841 Dostoevskii obtains a military commission; he begins experimenting with writing historical dramas à la Schiller and Pushkin (now-lost titles include Maria Stuart and Boris Godunov).

1842 Gogol's Dead Souls, part 1 is published.

1843 Dostoevskii passes his final engineering examinations, translates Balzac's Eugénie Grandet.

1844 Dostoevskii resigns his commission in the army and embarks on a literary career; he translates George Sand's La dernière Aldini, finishes Poor Folk in November.

1845 Poor Folk is well received by critics; Dostoevskii enters literary society.

1846 Poor Folk and The Double are published; The Double receives negative critical reviews.

1847 Dostoevskii writes for the St. Petersburg Gazette; first signs of epilepsy.

1848 Marx writes "The Communist Manifesto." 
1849 Dostoevskii begins work on Netochka Nezvanova; the novel remains unfinished when Dostoevskii is arrested for his membership in the Petrashevskii Circle; Dostoevskii is sentenced to death. The sentence is commuted at the last moment and he is sent to penal servitude in Siberia.

1850 Dostoevskii arrives at the prison in Omsk.

1851 The Crystal Palace is erected in Hyde Park for the Great Exhibition.

1852 Gogol' burns the second part of Dead Souls and dies.

1853 The Crimean War begins; Dostoevskii begins to experience periodic epileptic seizures.

1854 Dostoevskii is released from prison; begins his forced military service at Semipalatinsk; meets his future wife.

1855 Nicholas I dies; Alexander II ascends the throne.

1857 Dostoevskii marries Mariia Dmitrievna Isaeva; he publishes "The Little Hero," which he wrote while in prison in 1849.

1858 Dostoevskii begins writing again; writes The Village of Stepanchikovo and Uncle's Dream.

1859 Dostoevskii leaves the military; returns to St. Petersburg after ten years of exile. Darwin publishes The Origin of Species.

1860 Dostoevskii writes Notes from the House of the Dead and The Insulted and Injured; he joins his brother in editing the literary journal Time.

1861 Emancipation of the serfs; the first two parts of Turgenev's Fathers and Sons are published.

1862 Dostoevskii goes abroad for the first time, visits England, France, and Switzerland; meets Gertsen in London.

1863 Chernyshevskii's What Is to Be Done? is published. Dostoevskii publishes Winter Notes on Summer Impressions. Dostoevskii travels abroad again and begins an affair with Apollinariia Suslova.

1864 The Dostoevskii brothers found the journal The Epoch after Time is dissolved. Dostoevskii's wife dies in April and his older brother, Mikhail, in July. Dostoevskii works on Notes from Underground. Tolstoi publishes the first part of War and Peace.

1865 Epoch goes bankrupt and shuts down. Dostoevskii leaves Russia to escape his debts. Suslova rejects his proposal; Dostoevskii settles in Wiesbaden where he falls into gambling; he writes Crime and Punishment. 
xx $\quad$ Timeline of Dostoevskii's Life and Works

1866 Karakozov attempts to assassinate Alexander II. Dostoevskii returns to Russia, writes The Gambler, and meets Anna Grigor'evna Snitkina. Crime and Punishment is published.

1867 Marries Anna Grigor'evna; they settle in Dresden to escape his debts in Russia. The Umetskii trial takes place in St. Petersburg that fall.

1868 A daughter, Sofiia, is born, but dies several months later. The Idiot is serialized; the Dostoevskiis move to Italy.

1869 A daughter, Liubov, is born; the family moves to Dresden.

1870 Lenin is born; Dickens dies.

1871 Dostoevskii gives up gambling. A son, Fedor, is born in St. Petersburg. Demons is serialized.

1873 Dostoevskii becomes editor of The Citizen journal (resigns 1874).

1874 Dostoevskii is arrested and imprisoned again for censorship offenses. Dostoevskii travels to Bad Ems seeking a cure for emphysema. Dostoevskii travels to Staraia Russa for the first time.

1875 The Adolescent is published. A son, Aleksei, is born. Dostoevskii again travels to Bad Ems for his ailment.

1876 Dostoevskii begins publishing A Writer's Diary in The Citizen.

1877 The Russo-Turkish War breaks out; Tolstoi publishes Anna Karenina.

1878 Dostoevskii's son, Aleksei, dies; Dostoevskii begins work on Brothers Karamazov.

1880 Brothers Karamazov is published. Dostoevskii gives his "Pushkin Speech" at the unveiling of the Pushkin monument in Moscow; returns to Staraia Russa.

1881 Dostoevskii dies on February 9 (January 28, old style) and is buried in the Aleksandr Nevskii lavra in St. Petersburg. Alexander II assassinated March 13 (March 1, old style) 